\title{
Geomagnetic secular variation in Late Weichselian Allerød sediments from Nr. Lyngby (Denmark)
}

\author{
NIELS ABRAHAMSEN \& PETER W. READMAN
}

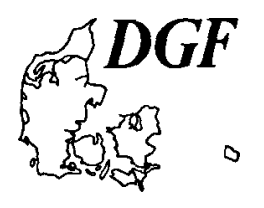

\begin{abstract}
Abrahamsen, N. \& Readman, P. W.: Geomagnetic Secular Variation in Late Weichselian Allerød Sediments from Nr.Lyngby (Denmark). Bulletin Geological Society of Denmark, Vol. 44, pp. 45-58. Copenhagen 1997-03-15. https://doi.org/10.37570/bgsd-1998-44-03
\end{abstract}

Palaeomagnetic measurements on 400 specimens from lake sediments exposed in the cliff of the classic Late Glacial Allerød site at Nørre Lyngby in North Jutland, Denmark, are presented. Two profiles in the $7 \mathrm{~m}$ sequence of sand, silt and gyttja, spanning the time interval between c. 12000 and c. 10 700 BP show about 5 cycles in the declination and about 2 cycles in inclination. Secular vari-ation features as observed at this site are also recognizable at sites in southern Sweden and Soviet Karelia. Comparisons with Holocene records indicate that the short time-scale behaviour (i.e. $\leq$ $10^{3} \mathrm{y}$ ) of the geomagnetic field appears to have been similar since $14000 \mathrm{BP}$, i.e. for a period considerably longer than the timescale of the variations themselves, thus suggesting that this type of behav-iour is a permanent feature of the geomagnetic field. These secular variation features may be useful in local as well as more regional stratigraphical correla-tions for the Late Glacial and Holocene on a much more detailed timescale than is obtained from the magnetic reversal timescale used for older materials.

Key words: Allerød,Nr. Lyngby, Denmark, geomagnetism, paleomagnetism, secular variation, sediments.

Niels Abrahamsen, Department of Earth Sciences, Finlandsgade 8, DK-8200 Aarhus N, Denmark. Peter W. Readman, School of Cosmic Physics, Dublin Institute for Advanced Studies, 5 Merrion Square, Dublin 2, Ireland. July 2nd, 1996.

Most sediments contain minute proportions of ferromagnetic minerals which are able to record directional variations in the Earth's magnetic field through time (Butler 1992). Measurements of the direction of magnetization of a set of sequential samples through a dated sequence therefore enables us to investigate, and so 'replay' the recorded 'magnetic tape' of the geomagnetic secular variation. Knowledge of the secular variation is now fairly well established for most of the Holocene (c. 10 000-0 BP) in Northern and Central Europe, but it is less well known for Late Weichselian (c. $15000-10000 \mathrm{BP}$ ), and indeed for earlier times. Unless otherwise stated, all ages in the present paper are reported as conventional ${ }^{14} \mathrm{C}$-ages before the present (conventional ${ }^{14} \mathrm{C}$ years BP, i.e. before 1950). The transformations are given in Table 1, and are also illustrated in Figure 1.

The secular variation is recorded in sediments by syn- and post-depositional processes. The knowledge of this pattern for specific time periods and regions may thus be useful for correlation and stratigraphical purposes, in particular where other methods are difficult, or are not available. The correlations can be very detailed and can be used to enhance any existing suatigraphical correlations. They are on a much more detailed timescale than it is possible to obtain by means of the more conventional magnetostratigraphy, which is based upon the magnetic reversal timescale (Harland et al. 1982). Reversals typically have transition periods (and hence an optimum time-resolution) of $\geq 5000$ $\mathrm{y}$, whereas the secular variations have periods as short as c. $200 \mathrm{y}$. The reversal timescale is also of limited use during the Pleistocene since the last major field reversal occurred c. $0.78 \mathrm{Ma}$ ago. Although more recent 'excursions' of the field have been reported (reviews by Tarling 1983, Novaczyk et al. 1994), their geographical extent are often not well known yet, and the existence of some of these excursions are still con- 


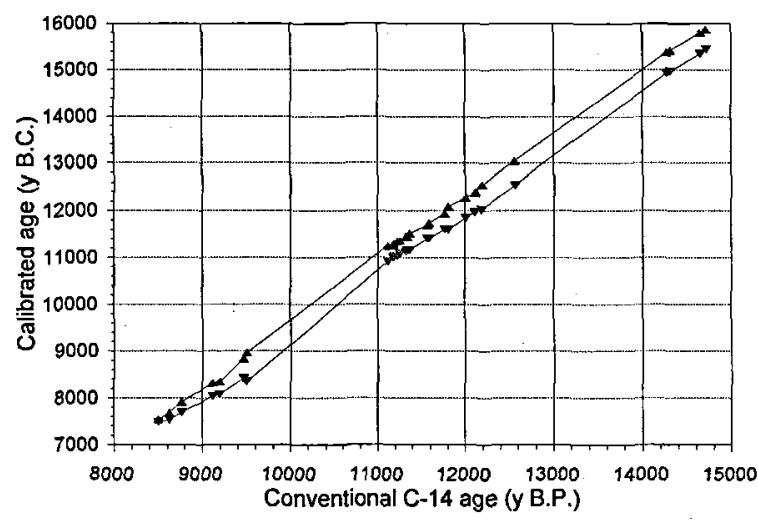

Figure 1. Relationship between conventional ${ }^{14} \mathrm{C}$ ages (in years BP) and the calibrated ages (in years $\mathrm{BC}$ ) for the ${ }^{14} \mathrm{C}$ dates in Table 1, according to curves in Struiver \& Reimer (1993). The vertical distance between the curves indicate the $1 \sigma$-range.

troversial. Once the pattern of the secular variations has been established for a region, the time resolution possible may be as short as about $200 \mathrm{y}$, or even less.

\section{Previous work on secular variation}

Lake sediments have provided the most continuous record of the directional changes of the Earth's magnetic field through the Holocene. Although exact correlation between different locations is sometimes not straightforward, mainly because of dating uncertainties, a general pattern of declination and inclination variations can usually be seen within Europe. Holocene data from UK have been published by (Mackereth 1971, Thompson \& Turner 1979; Turner \& Thompson 1981), from France by (Thouveny et al. 1990), from Switzerland by (Creer et al. 1980), from Denmark by (Readman \& Abrahamsen 1988, 1990), from Norway by (Abrahamsen et al. 1995), from Finland by (Huttunen \& Stober 1980; Saarinen 1995), and from Poland by (Creer et al. 1979).

In addition to lake sediments, archaeological samples have been used, and with their often better absolute dating control such materials have produced detailed records in more recent times, from UK for example Aitken (1979), Clark et al. (1988), Tarling (1989), from Bulgaria Kovacheva (1980), from France Thellier (1981), from Germany Schnepp \& Pucher (1997). They have been an important control for the work on sediments, but suffer from their limited timescale which usually does not provide a continuous, nor indeed necessarily sequential, record. Marine sediments, although they have been widely used in magnetostratigraphy with ocean sediments using the magnetic reversal timescale, have limited use for deriving the secular variations of the geomag-netic field. Attempts to use them for secular variation studies have consequently been few, being restricted to regions where the sedimentation rates are possibly high enough to record the secular variations, e.g. the Baltic Sea (Abrahamsen \& Readman 1987; Abraham-sen 1995) and glaciomarine sediments in the Kola Peninsula (Bakhmutov et al. 1994).

For the Late Weichselian (15 000-10 000 BP) the geomagnetic record is not so well defined because of the lack of suitable sediments within this period, particularly in northern Europe. Most records have been obtained from fairly short time sections (Abrahamsen 1982, 1995; Creer et al. 1986; Smith \& Creer 1986; Björck \& Sandgren 1986; Björck et al. 1987; Sandgren 1986). By carefully combining records from several overlapping sections for the same region, Bakhmutov \& Zagniy (1990) have been able to build a record through the whole period for Soviet Karelia. In Denmark only geomagnetic field variations for the timespan representing the Younger Yoldia Clay (c. $14600-$ $13000 \mathrm{BP}$ ) has, as yet, been well determined from palaeomagnetic measurements (Abrahamsen \& Knudsen 1979; Abrahamsen \& Readman 1980), the sites of these investigations actually being quite close to the present one at Nr. Lyngby.

To facilitate comparisons with other investigations of late Weichselian sequences, the transformations of conventional ${ }^{14} \mathrm{C}$ years BP (i.e. before 1950 ) to calibrated ages $\mathrm{BC}$ for a number of relevant datings are summarized in Table 1. The data are based upon the information given in the cited litterature, and the conventional ${ }^{14} \mathrm{C}$ age has been recalculated to calibrated ages according to Stuiver and Reimer (1993). In Figure 1 the results from Table 1 are shown graphically, the vertical distance between the curves indicating $1 \sigma$ range. For the interval 12000 to 10700 conv. ${ }^{14} \mathrm{C}$ years BP the calibrated ages are roughly about 2000 years older. Specific discussions about the age transformations may be found in Stuiver \& Reimer (1993), Rasmussen (1994) and Björk (1996).

The purpose of the present paper is to help fill in the gap in the geomagnetic secular variation record for Denmark. Palaeomagnetic results from the classic and well exposed limnic sequence at Nr. Lyngby, covering the Allerød warm period, are presented. The whole sequence spans the time interval from about 12000 conv. ${ }^{14} \mathrm{C}$ years BP to 10700 conv. ${ }^{14} \mathrm{C}$ years BP.

\section{Geological setting and chronology}

On the North Sea coast of North Jutland, Denmark (Figure 2), about $20 \mathrm{~m}$ of Late Weichselian freshwater sediments are well exposed in a section in the coastal cliffs at Nr. Lyngby, situated at $57^{\circ} 24.91^{\prime} \mathrm{N}$, $9^{\circ} 44.80^{\prime}$ E. Detailed geological investigations have 
Table 1. Conventional ${ }^{14} \mathrm{C}$ ages $\pm 1 \sigma$ and corresponding calibrated ages $\mathrm{BC}$ (one sigma range) of some datings relevant to the magnetic records. The calibrations are according to the curves in Struiver \& Reimer (1993) (courtesy of Kaare Lund Rasmussen).

$\begin{array}{lllll}\text { Lab. No. } & \begin{array}{l}\text { Conven- } \pm 1 \sigma \\ \text { tional }\end{array} & \begin{array}{l}\text { Calibrated*) } \\ \text { age BC over }\end{array} & \text { Material } & \text { Reference } \\ \text { y B.P. } & \text { one sigma } & \\ \text { range } & \end{array}$

\begin{tabular}{|c|c|c|c|c|c|}
\hline Tln-1610 & 8505 & 60 & $7550-7490$ & Pholas crispata L. & Yevzerov \& Kolka 1993 (Quoted in Bakhmutov et al. 1994) \\
\hline Tln-1584 & 8630 & 50 & $7690-7540$ & Mya truncata $\mathrm{L}$. & Yevzerov \& Kolka 1993 (Quoted in Bakhmutov et al. 1994) \\
\hline $\mathrm{Tln}-1542$ & 8770 & 45 & $7920-7700$ & Pholas crispata L. & Yevzerov \& Kolka 1993 (Quoted in Bakhmutov et al. 1994) \\
\hline $\mathrm{Tln}-1569$ & 9120 & 70 & $8320-8040$ & Cyprina islandica & Yevzerov \& Kolka 1993 (Quoted in Bakhmutov et al. 1994) \\
\hline LU-328 & 9200 & 100 & $8350-8080$ & Pholas crispata L. & Kiselyov et al. 1974 (Quoted in Bakhmutov et al. 1994) \\
\hline $\operatorname{Tln}-1276$ & 9465 & 70 & $8840-8420$ & marine shells & Yevzerov \& Kolka 1993 (Quoted in Bakhmutov et al. 1994) \\
\hline LU-335 & 9500 & 160 & $8970-8350$ & & Kiselyov et al. 1974 (Quoted in Bakhmutov et al. 1994) \\
\hline Aar-1908 & 11,120 & 160 & $11250-10920$ & bone & Aaris-S $\varnothing$ rensen 1995 \\
\hline Aar-1909 & 11,180 & 130 & $11280-11000$ & bone & Aaris-Sørensen 1995 \\
\hline $\mathrm{K}-6189$ & 11,190 & 135 & $11300-11010$ & bone & Aaris-Sørensen 1995 \\
\hline Aar-1910 & 11,190 & 100 & $11260-11040$ & bone & Aaris-Sørensen 1995 \\
\hline Aar-1510 & 11,230 & 150 & $11350-11040$ & wood & Aaris-Sørensen 1995 \\
\hline Aar-1508 & 11,260 & 120 & $11360-11090$ & wood & Aaris-Sørensen 1995 \\
\hline BIRM 281 & 11,330 & 150 & $11460-11130$ & & Krogh 1978 \\
\hline Aar-1507 & 11,340 & 120 & $11440-11170$ & wood & Aaris-Sørensen 1995 \\
\hline $\mathrm{K}-6188$ & 11,370 & 165 & $11520-11160$ & bone & Aaris-Sørensen 1995 \\
\hline Aar-1511 & 11,570 & 110 & $11700-11410$ & bone & Aaris-Sørensen 1995 \\
\hline Aar-1509 & 11,590 & 130 & $11740-11410$ & wood & Aaris-Sørensen 1995 \\
\hline $\mathrm{K}-1988$ & 11,770 & 120 & $11950-11610$ & & Krogh 1978 \\
\hline $\mathrm{K}-1989$ & 11,810 & 170 & $12090-11600$ & & Krogh 1978 \\
\hline $\mathrm{K}-1943$ & 12,010 & 150 & $12280-11850$ & & Krogh 1978 \\
\hline $\mathrm{K}-1942$ & 12,110 & 130 & $12390-11980$ & & Krogh 1978 \\
\hline $\mathrm{K}-1938$ & 12,120 & 140 & $12410-11980$ & & Krogh 1978 \\
\hline $\mathrm{K}-1990$ & 12,190 & 180 & $12560-12030$ & & Krogh 1978 \\
\hline $\mathrm{K}-2111$ & 12,560 & 130 & $13040-12550$ & & Krogh 1978 \\
\hline $\mathrm{K}$ & 14,270 & 180 & $15380-14930$ & Y.Yoldia Clay & Knudsen 1978 \\
\hline $\mathrm{K}-2413$ & 14,310 & 180 & $15430-14980$ & U.Saxicava Sand & Knudsen 1978 \\
\hline $\mathbf{K}$ & 14,650 & 190 & $15810-15360$ & Y.Yoldia/L.Sax. & Knudsen 1978 \\
\hline $\mathrm{K}-2671$ & 14,720 & 180 & $15880-15450$ & Hiatella arctica L. & Abrahamsen \& Readman 1980 \\
\hline
\end{tabular}

${ }^{*}$ Calibrated according to the curves in Stuiver \& Reimer (1993), using the University of Washington calibration program CALIB Ver. 3.0.3.C.

Figure 2. Index-figure of Denmark with the site of Allerød lake sediments at $\mathrm{Nr}$. Lyngby indicated.

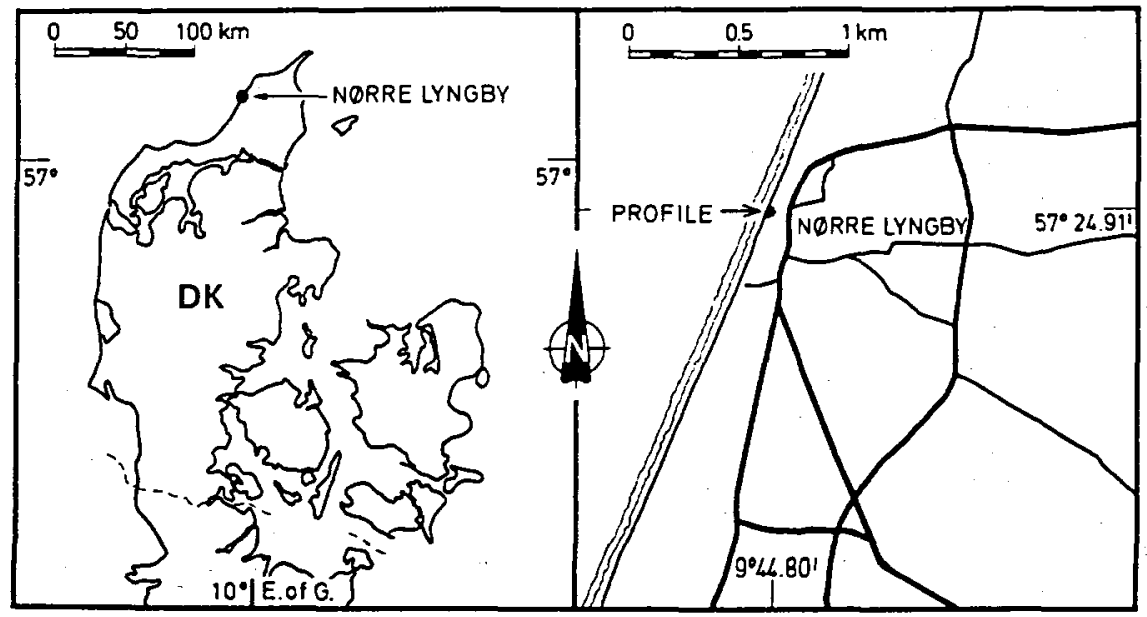




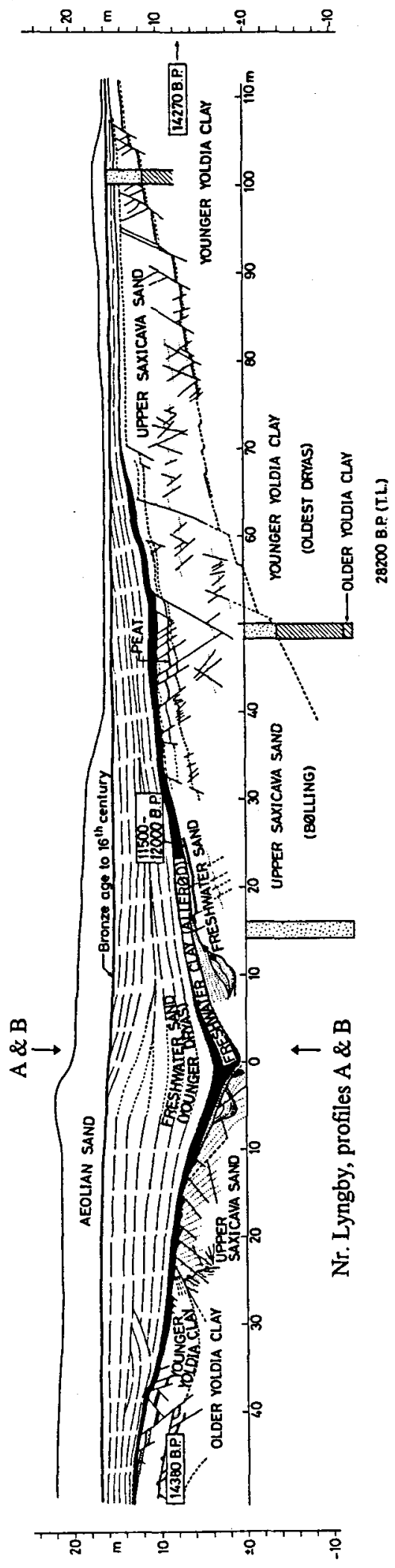

been described by Jessen \& Nordmann (1915), Jessen (1931, 1936), Iversen (1942), Krog (1978) and AarisSørensen (1995). The timing and pattern of the deglaciation in Denmark is described by Lagerlund \& Houmark-Nielsen (1993).

The sediments in this (former) lake were deposited in a minor, east-west elongated depression, probably of tectonic origin (Lykke-Andersen 1992). The lake sediments rest on top of isostatically elevated Late Weichselian marine deposits of the Younger Yoldia Clay and the Upper Saxicava Sand (Figure 3). Radiocarbon dates of between c. 14600 and 12000 BP have been obtained for these marine deposits (Krog 1978, Knudsen 1978, Abrahamsen \& Readman 1980, AarisSørensen 1995). The Upper Saxicava Sand is considered to have been deposited during the Bölling Interstadial 13 000-12 000 BP (Knudsen 1978, Knudsen et al. 1986).

The lake sediments have been studied in detail and have been radiocarbon dated by conventional (Krog 1978 ) as well as AMS C-14 dating techniques (AarisSørensen 1995). They show a basal sequence of up to $4 \mathrm{~m}$ of laminated yellowish freshwater sand of Older Dryas age (c. 12 000-11 800 BP; Mangerud et al. 1974 ) including thin peat layers (Krog 1978), superposed by c. $2 \mathrm{~m}$ of dark grey to greyish-black Allerød gyttja and silts (c. 11 800-11 000 BP). On top of this some 6-8 $\mathrm{m}$ of yellowish-grey laminated silty sand of Younger Dryas age (c. 11 000-10 000 BP) terminates the lake sediment sequence. Following a hiatus between c. 10000 and $400 \mathrm{BP}$, the top of the profile is covered with 3-5 m of recent aeolian sands.

Based on the above ages, the section sampled for palaeomagnetic investigation is estimated to span slightly more than one millenium, namely the time interval between c. $12000( \pm 100)$ years and 10700 $( \pm 200)$ years BP (the top part of the Younger Dryas sand not being sampled). The rate of deposition of the most gyttja-rich part of the sequence (spanning some $800 \mathrm{y}$ ), is about 2 to $3 \mathrm{~mm} / \mathrm{y}$, while that of the more sandy parts below and above the gyttja (spanning time intervals of some 200 to $400 \mathrm{y}$, respectively), is about 5 to $10 \mathrm{~mm} / \mathrm{y}$ (see Figure 3 ).

\section{Palaeomagnetic sampling}

A series of vertical undisturbed subsections were cut back and cleaned in the open cliff section. Correlation between the subsections was made by careful inspection of details in the lithology, such as laminations. Two parallel palaeomagnetic profiles, A and B,

Figure 3. Geological profile at Nr. Lyngby, showing the general stratigraphy of the lake sediments in the former Late Weichselian lake depression. The location of the two paleomagnetic profiles A \& B are also indicated. (Modyfied from Knudsen et al. 1986). 


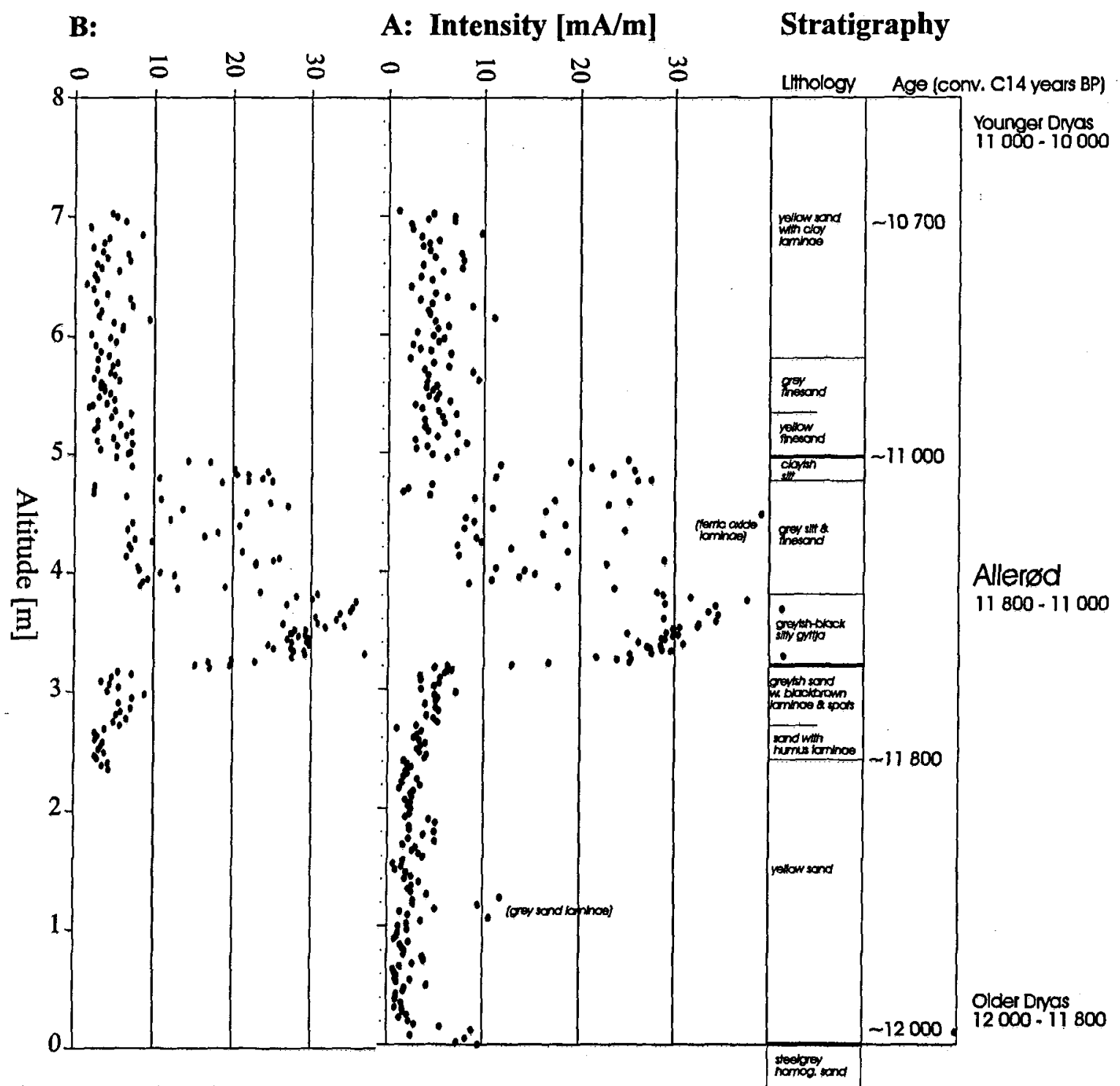

Figure 4. NRM intensity, stratigraphy, age and lithology of the sediment sequence exposed at Nr. Lyngby; ages in Conventional ${ }^{14} \mathrm{C}$-years BP (chronostratigraphy according to Mangerud et al. 1974). Left: NRM intensity of profile B. Center: NRM intensity of profile $A$. Right: stratigraphy, age and lithology.

approximately $20 \mathrm{~cm}$ apart were sampled by pressing polystyrene cubic sample holders horizontally into the soft sediment with the use of a sensitive wooden spirit level to ensure accurate horizontal orientation. The azimuth of each specimen was measured with a magnetic compass, the local magnetic declination being known to better than $1^{\circ}$. A total of about 400 specimens were thus collected. All heights are measured from the top of the grey homogeneous sand at the base of profile A, close to present day sea level.

The longest profile (A) covered most of the limnic sequence, i.e. about $7 \mathrm{~m}$. The $B$ profile duplicated the central and upper part of the A profile, but omitted the lowermost $2.4 \mathrm{~m}$ of the more sandy sediments, which were not expected to be suitable material for a palaeomagnetic investigation.

\section{Magnetic results}

NRM, susceptibility and Q-ratio

The natural remanent magnetization (NRM) was measured by means of a Digico spinner magnetometer. In Figure 4 the NRM intensity $\mathrm{J}_{0}$ is shown for both pro- 
A: Susc [10-6 emu]

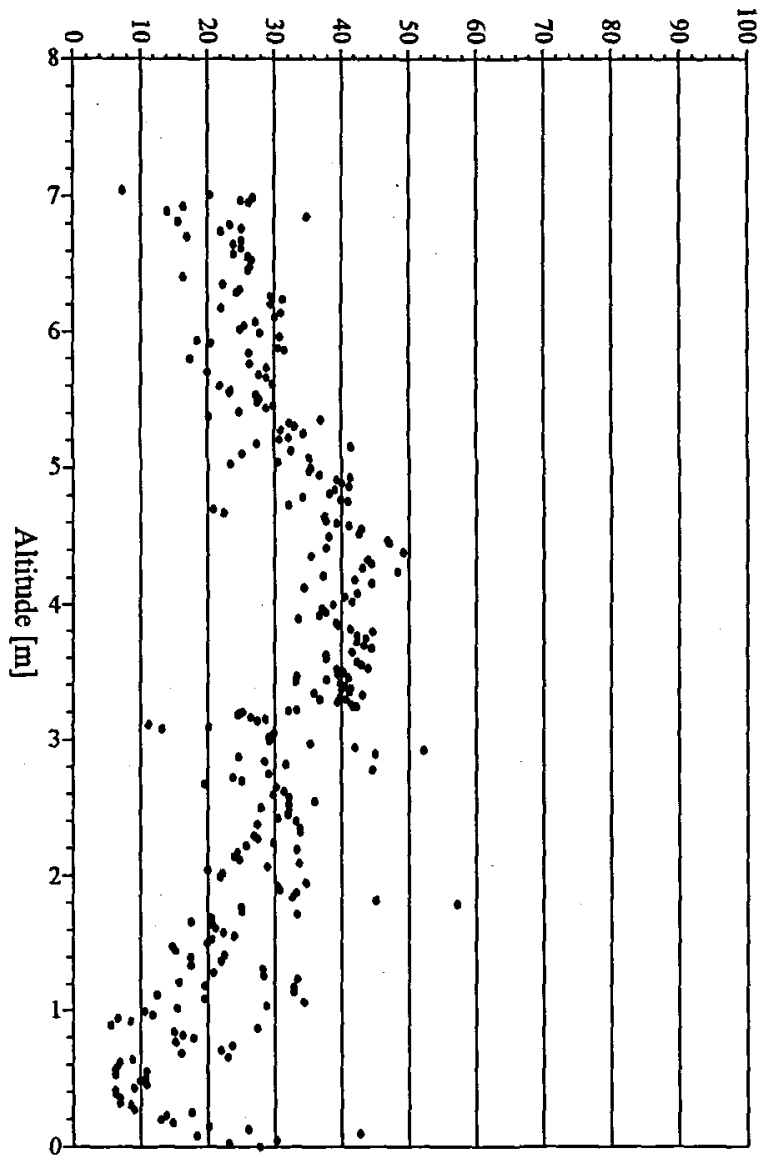

Figure 5. Magnetic susceptibility (k) of profile A.

files. Between 0-3.2 $\mathrm{m}$ the values vary between 1 to 5 $\mathrm{mA} / \mathrm{m}$ (more silty), with a few specimens at the base of the section and at about $1 \mathrm{~m}$ having higher values close to $10 \mathrm{~mA} / \mathrm{m}$, which correspond to individual grey sand lamellae (one extreme value of $60 \mathrm{~mA} / \mathrm{m}$ is due to a thin black band). Two levels of intensity between about 2.45-2.75 $\mathrm{m}$ and between about $2.75-3.2 \mathrm{~m}$, are distinct ( $\sim 3$ and $5 \mathrm{~mA} / \mathrm{m}$, respectively) and correspond to slight changes in lithology and colour. The gyttja and grey clayish silt between 3.2 and $5 \mathrm{~m}$ show much higher intensities up to around $40 \mathrm{~mA} / \mathrm{m}$. The values are highest in the dark grey gyttjas, becoming more scattered in the grey silt and more sandy part, where they average around $16 \mathrm{~mA} / \mathrm{m}$. The NRM intensity appears to be directly related to the gyttje/ silt-ratio. Above $5 \mathrm{~m}$ the values are scattered in the range 2 to $9 \mathrm{~mA} / \mathrm{m}$, and somewhat more scattered than those in the section below the gyttja. In general, extreme individual intensities correspond to samples originating from the more darker coloured laminae. All these features are clearly found in both profiles and confirm the tight stratigraphical correlation.

\section{A: Q-ratio}

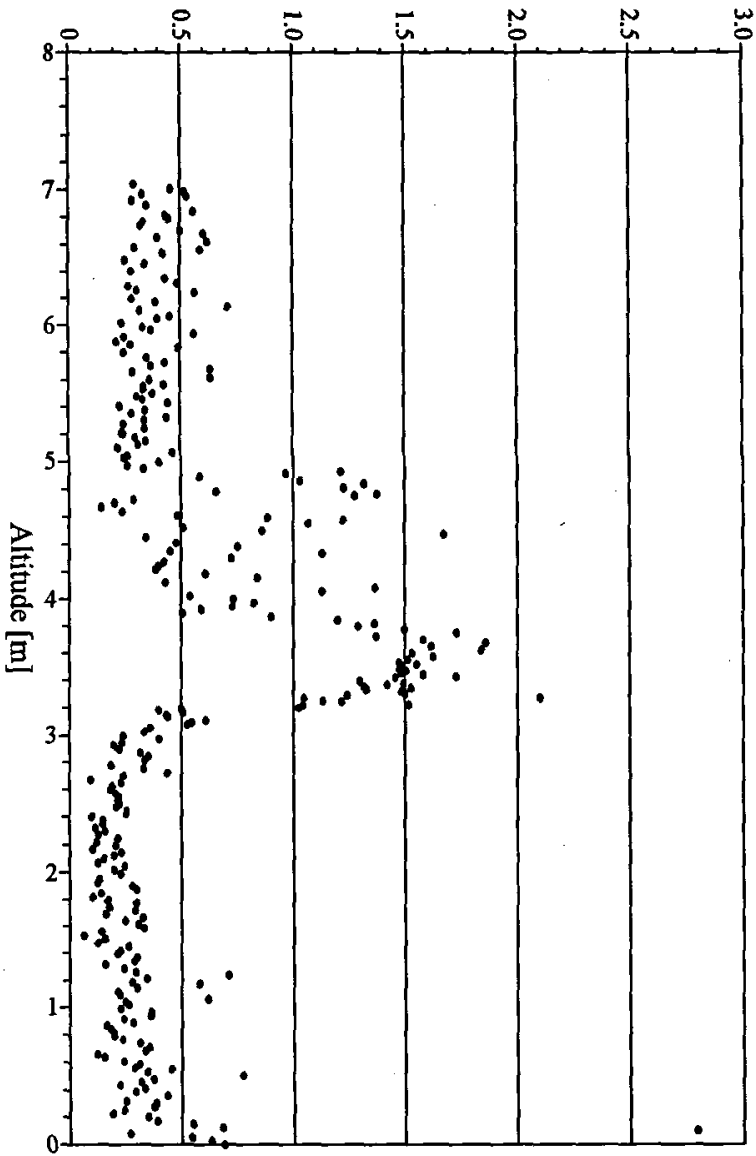

Figure 6. Modyfied Q-ratio $\left(\mathrm{Q}=\mathrm{J}_{\mathrm{NRM}} / \mathrm{k}\right)$ of profile $\mathrm{A}$.

The low field reversible magnetic susceptibility was measured with a Digico susceptibility bridge (1 Oe, $10 \mathrm{~Hz}$ field) and is shown for profile A in Figure 5. The values range from about $(0.07-0.6) \times 10^{-3}$ SI units. There is not such a clear correlation with lithology as in the case of the NRM intensity but nevertheles the variations noted in the latter can be easily detected. The overall variation along the profile is more gradual, but very scattered, with isolated anomalous values having a much less obvious signature than in the intensity record (Figure 4 ). The dominant long timescale variation seen could be the result of the gradual climatic change, which correlates with the formation of the Allerød gyttja. This induced variations in such factors as erosion, deposition and in-situ (i.e. postdepositional) production of the magnetic minerals. The rapid variations and isolated scattered values are likely to be the result of very local rapidly varying depositional conditions (e.g. erosion resulting from a heavy rainfall, a dry season, etc.).

Both parameters depend upon the quantity and type as well as the magnetic grain size of the magnetic 


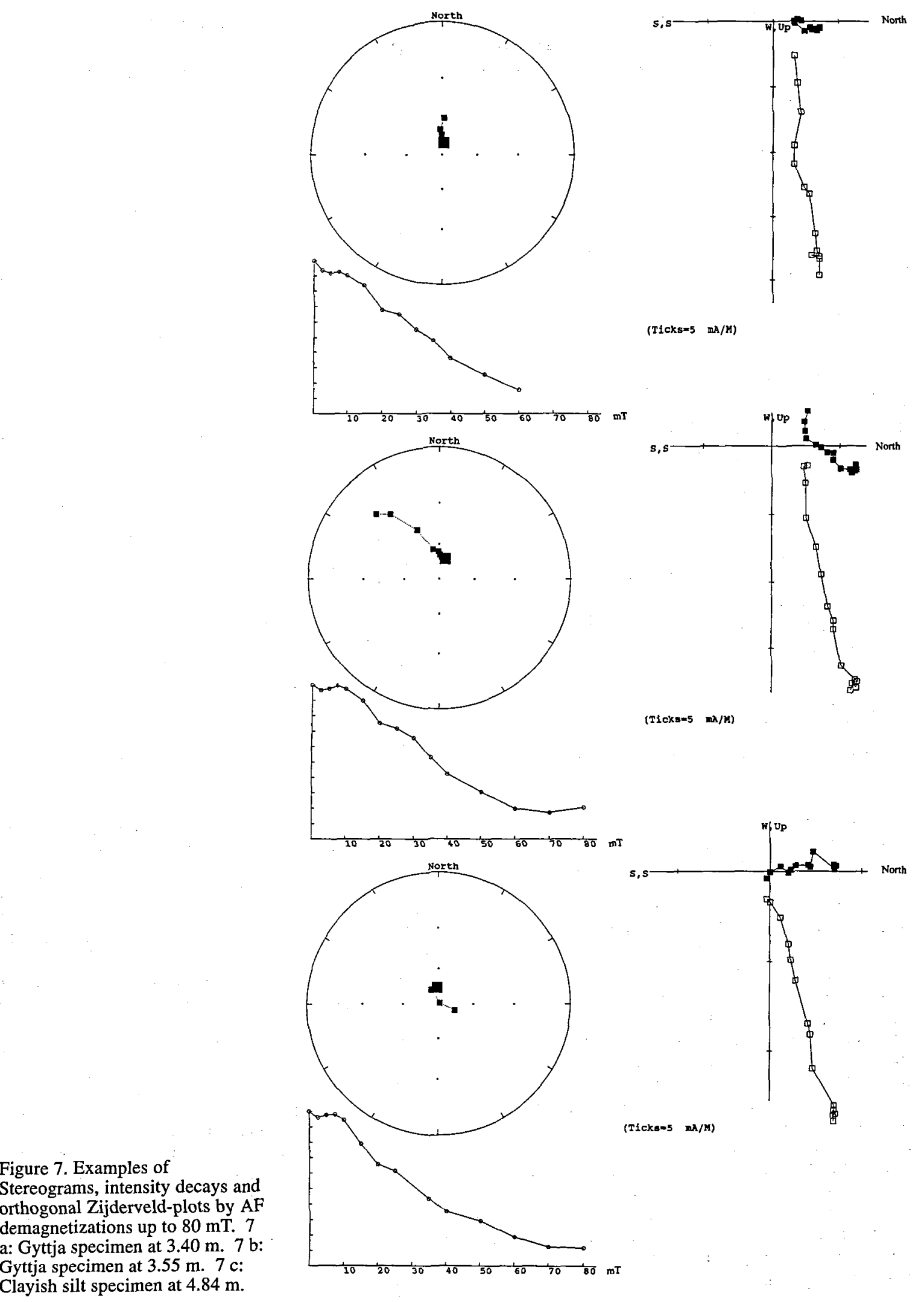

Figure 7. Examples of Stereograms, intensity decays and Clayish silt specimen at $4.84 \mathrm{~m}$. 


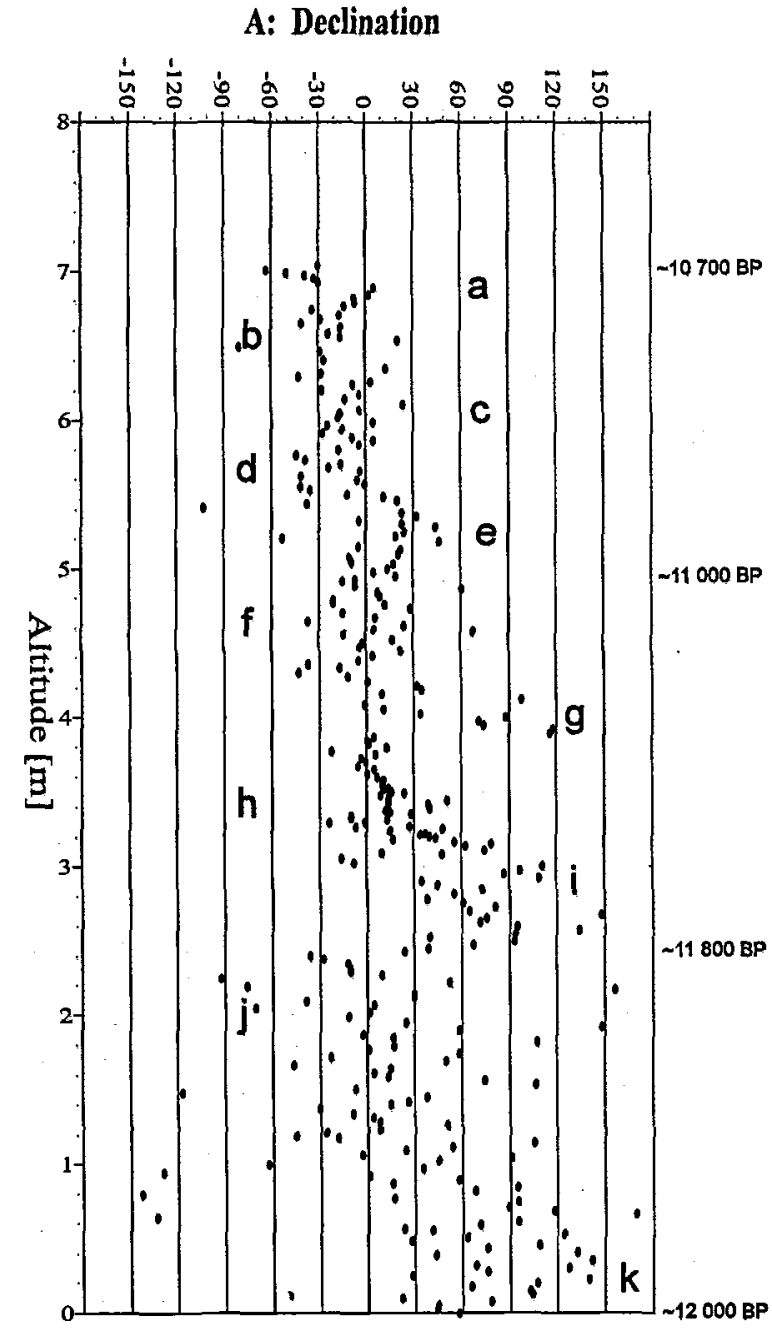

Figure 8. Declination. 8a: Declination of profile A. Peaks in the declination are labelled $a-k$.

minerals contained in the sediment, but in addition the remanence depends also on the magnetizing field intensity. The ratio of the susceptibility to NRM intensity (the modified Q-ratio, $Q=J_{N R M} / k$ ) of section $A$ is plotted in Figure 6. In the simplest case where the only variable in magnetic mineralogy of the sediment is the quantity of magnetic mineral, the Q-ratio should reflect variations in the intensity of the Earth's magnetic field. The fact that the NRM intensity shows much greater and more abrupt changes in magnitude than the susceptibilty, suggests that the magnetic mineralogy is complex. It also shows that for these sediments the Q-ratio cannot be used as a normalizing parameter to obtain the secular variation of the intensity of the geomagnetic field. In the predominantly sandy parts of the section the very low NRM intensity probably results from the magnetic particles being attached to the surface of the much larger sand

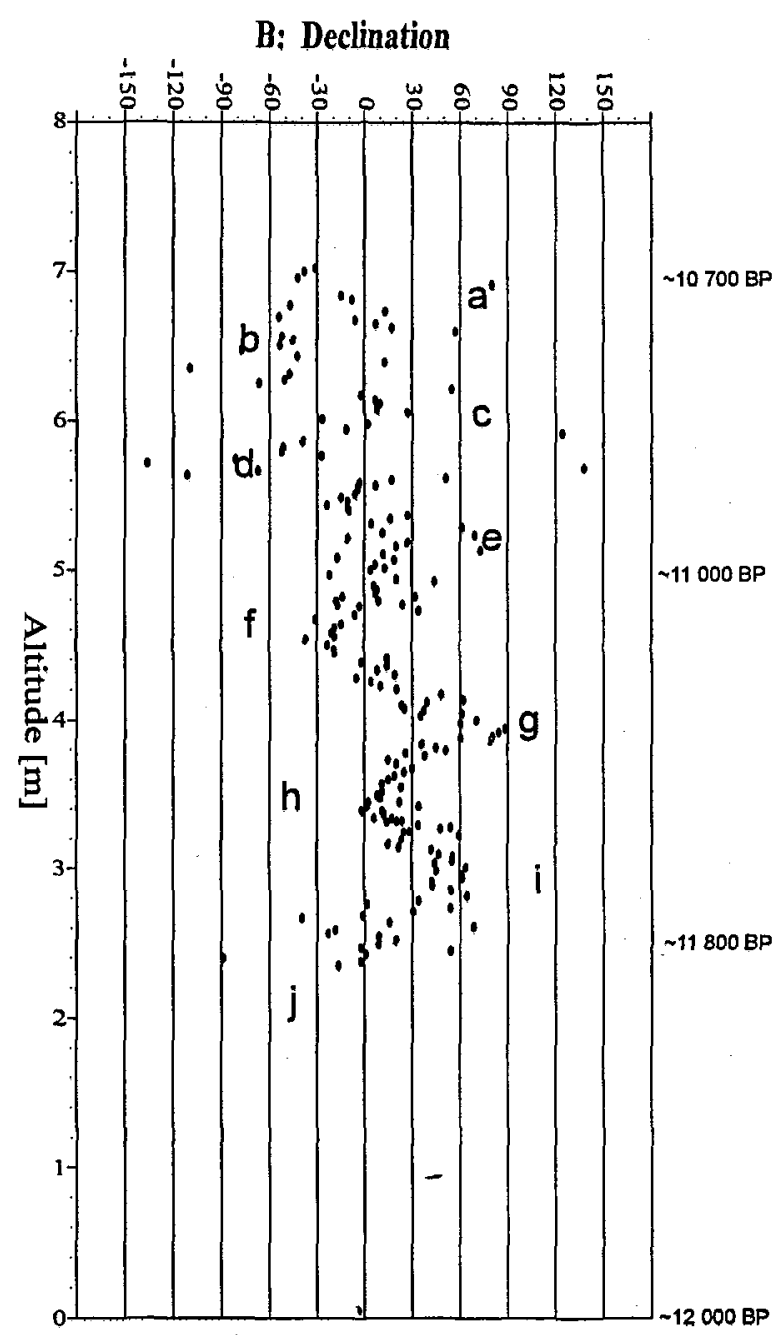

8b: Declination of profile $B$. Peaks in the declination are labelled $a-j$.

grains. The much larger gravitational forces, compared to the magnetic alignment forces acting on the sand grains means that any movement of the grains will perturb and so tend to randomize, or effectively demagnetize, the remanence.

\section{AF demagnetization}

A total of 16 specimens were chosen from representative horizons for detailed stepwise AF (alternating field) demagnetization up to a maximum field of 80 $\mathrm{mT}$. Results from two specimens from the gyttja-rich part (at 3.40 and $3.55 \mathrm{~m}$ ) and one from the upper more silty part (at $4.84 \mathrm{~m}$ ) are illustrated in Figure 7. The stereograms and orthogonal plots show there is good directional stability, and in general the results indicate a fairly stable remanence, with median destruc- 
tive fields in the range of 20 to $40 \mathrm{mT}$. Samples with a high NRM intensity, greater than about $10 \mathrm{~mA} / \mathrm{m}$, show little directional scatter. In contrast, some of the more weakly magnetized samples show considerable scatter in the direction of the remanence on demagnetization, but they also show a generally consistent direction.

Samples were originally stored in a reduced field (less than $50 \mathrm{nT}$ ) for up to two weeks before the first measurements were made, and subsequently for several further weeks before remeasurement. Specimens from profile A were bulk demagnetized at 10,20 and $40 \mathrm{mT}$ AF fields. The features identified in the declination and inclination records (Figs 8-9) were seen in all the demagnetized records, but the demagnetization introduced additional scatter into the observed patterns which increased with increasing AF fields. On balance, the measurements after reduced field storage are considered to give the most reliable record of the directional variations in the remanence.

\section{Declination and inclination}

The declination and inclination records of the two profiles are shown in Figures 8 and 9, respectively. There is a general long term trend in declination from easterly directions averaging about $60-90^{\circ} \mathrm{E}$ at the base of the section A to predominantly westerly directions at the top, reaching about $30^{\circ} \mathrm{W}$, on average. In addition to this long term trend, shorter period variations, or swings, can be seen. Swings are labelled by the lowercase letters $(a-k)$ for section $A$ and $(a-j)$ for section B. The same features are identified in both sections. The peak-to-peak amplitude of these shorter period variations range from about $30^{\circ}$ to $90^{\circ}$.

As found in the declination, a long period variation is found in the inclination. Relatively low values are seen at the lower and top parts of the section, and a maximum of about $80^{\circ}$ at around $4 \mathrm{~m}$. A pattern of inclination variations is not as well defined as in the case of declination. This is probably due to the high content of sand giving rise to a grain size dependant inclination error (King, 1955) as is often found in investigations using sandy and coarser grained sediments. In particular, only a rather vague pattern can be discerned in the lower and the uppermost parts of the sections, varying by about $10-15^{\circ}$. However, we are able to identify about four to five features in both inclination records and these peaks and troughs are labelled with uppercase letters (A-F) in Figure 9. The average inclination for the whole of profile $\mathrm{A}$ is $67.6^{\circ}$; that of the lower sandy part $(0-2.20 \mathrm{~m})$ is $62.9^{\circ}$ which when excluded increases the average inclination to very close to the axial dipole value of $72.3^{\circ}$ for this site.

\section{Discussion}

The fact that the directional variations in the magnetic record are clearly seen in both profiles, which are independantly correlated from the observed lithology, and that the NRM shows good directional stability on AF demagnetization strongly suggests that these variations reflect the geomagnetic secular variation. Independant dating of the sediments from nearby locations have indicated that the time period spanned by this record is approximately between 12000 and $10700 \mathrm{BP}$.

Comparison with the contemporaneous palaeomagnetic record from three Late Weichselian cores from the Torreberga basin in Skåne, South Sweden (Sandgren 1986; Ising 1990), some $300 \mathrm{~km}$ SE of Nørre Lyngby, shows that the inclination swings noted above (Figs 9a-9b, labels B-E) agree reasonably well with the swings of the Torreberga basin (labelled e, $\mathrm{f}, \mathrm{g}$ and j, respectively, in Sandgren (1986 Fig. 10). In the declination, a major westward swing is seen in the Torreberga core between 11 500-10 400 BP (dates from Ising 1990, Fig. 7), and minor eastward swings are also seen around 12 000,11300,10800 and 10 200 BP in the Torreberga cores (Fig. 9 in Sandgren 1986), but the fit in declination with our profiles (Figs $8 a-8 b$, labels $a-g$ ) is less convincing. This could in part be explained by the compressed depth scale of the Torreberga cores. About $10 \mathrm{~cm}$ of core represents the timespan 11 000-11 200 BP and has been stretched to fit the top and bottom dates of the Allerød Chronozone in this area (Berglund \& Digerfeldt 1970; Sandgren 1986; Ringberg 1989; Ising 1990). Thus this part of the time scale is not sampled in detail by the Torreberga cores and this part of the palaeomagnetic record derived from them is expected to be very much smoothed.

The secular variation results from Soviet Karelia (Bakhmutov \& Zagniy 1990) covering the whole Late Weichselian in this area (16 000-10 000 BP) are of very good quality, and appear to have good dating control. They show both long-period as well as shortperiod variations in both declination and inclination. However as this site is a long way from our Nr. Lyngby site (1400 km to the ENE) the two secular variation patterns are not to be expected to correspond exactly. We suggest, however, that our easterly declination swing $(\mathrm{g})$ in Figures $8 \mathrm{a}$ and $8 \mathrm{~b}$ may correspond to the eastward peak defined by the clustering of points at 11100 in the Karelia record. The pronounced eastward swing (k) at 12000 is seen at both localities. The broad inclination high between 12 000-11 700 BP in Karelia are likely to correspond to our (more vague) high inclination pattern between 11600 and $11300 \mathrm{BP}$.

We note here that agreement with this kind of data would not be expected to be perfect, and may require some detailed assumptions about deposition rates at the two sites during the Allerød interstadial. The dif- 


\section{A: Inclination}

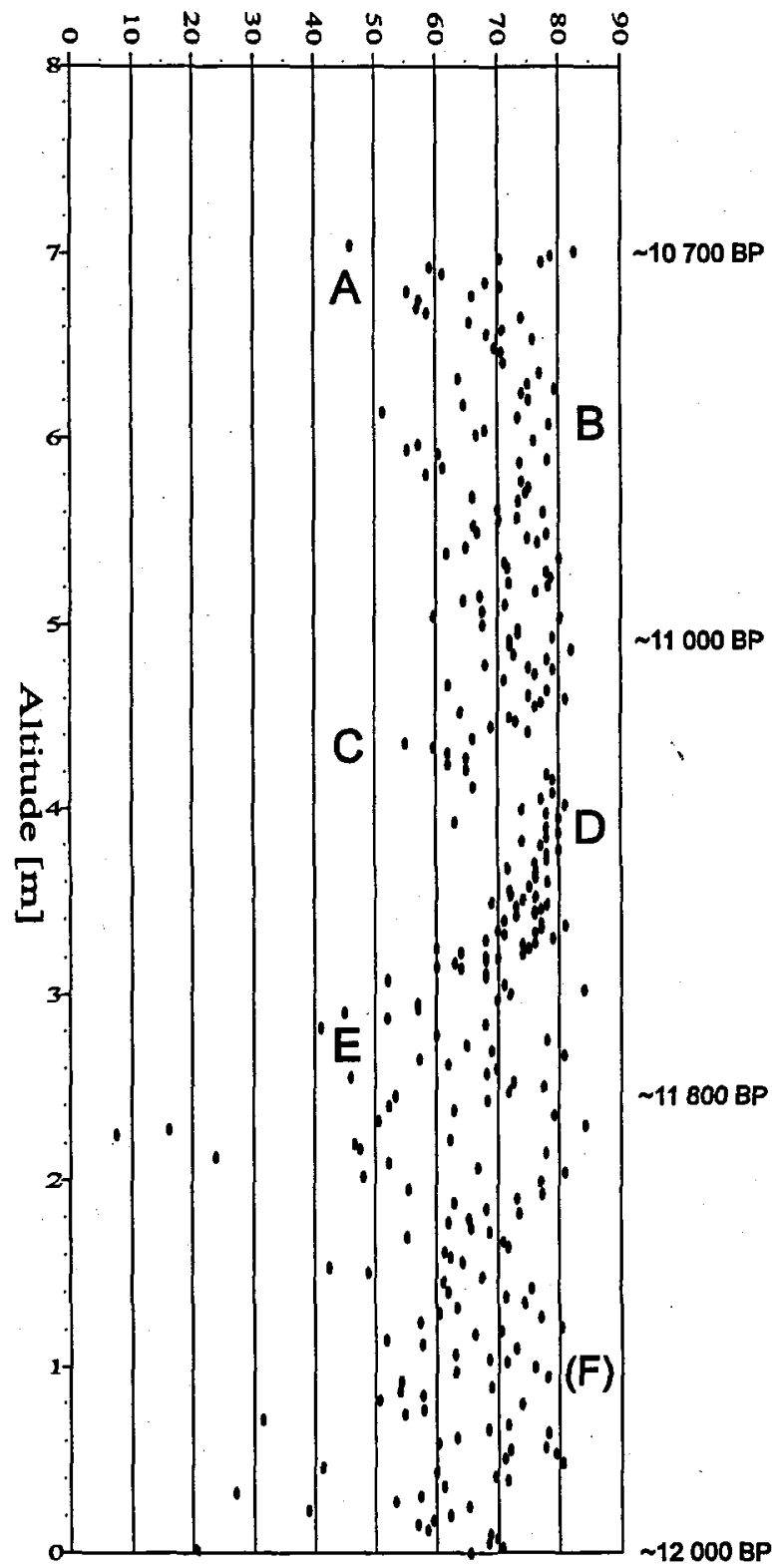

Figure 9. Inclination. 9a: Inclination of profile A. Peaks in the inclination are labelled A-F.

ferences are probably due partly to some scatter in parts of the Nørre Lyngby record, partly due to minor uncertainties in the datings, and partly due to the difference in the rates of deposition at the two sites during the Allerød. Hence differences in resolution of the short-period behaviour of the geomagnetic field are certainly to be expected at different sites. Furthermore as this field is not a simple dipole field but involves multipole contributions of local, as well as more regional high-order elements (Merrill \& McElhinny
B: Inclination

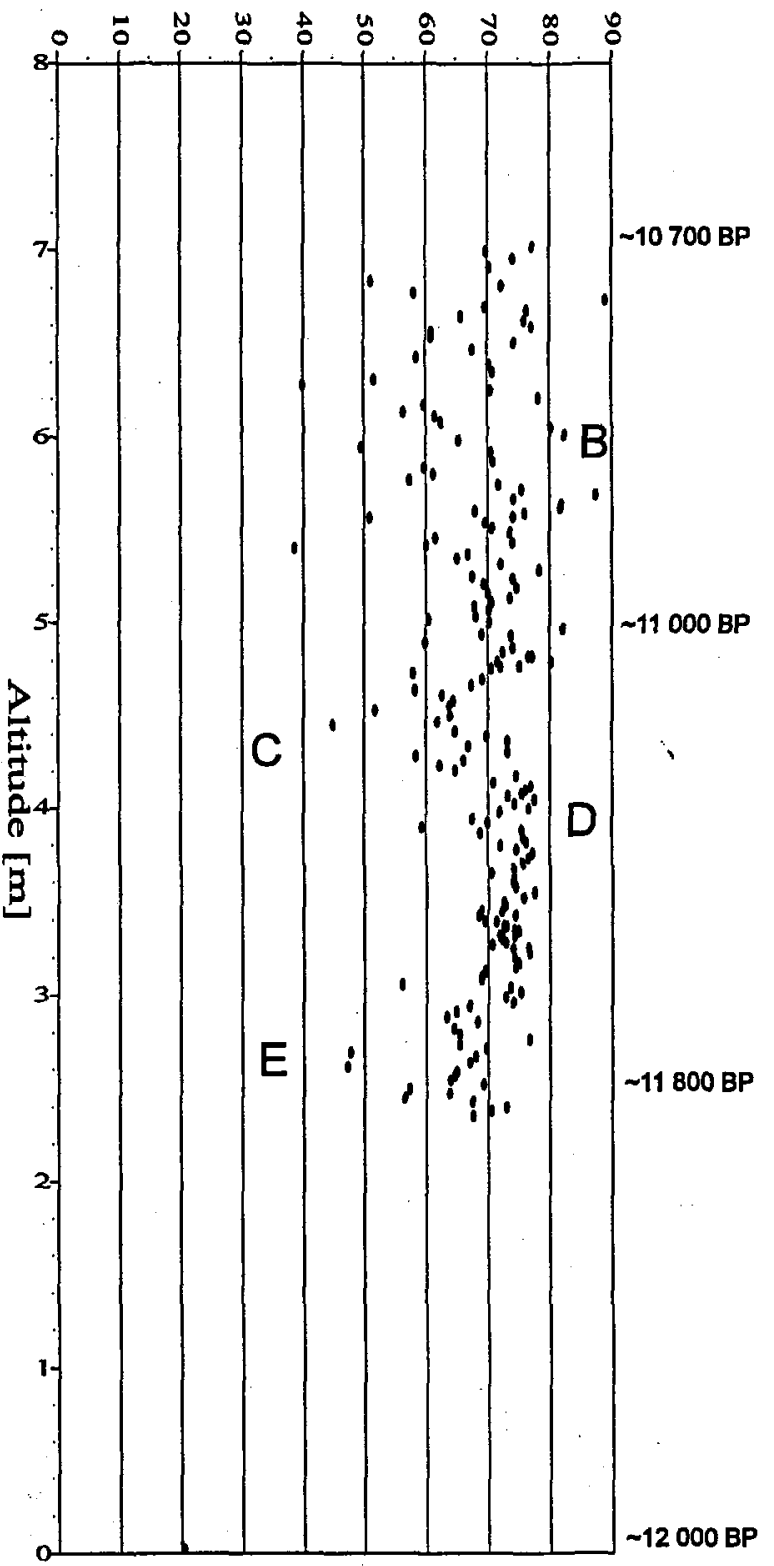

$9 \mathrm{~b}$ : Inclination of profile $\mathrm{B}$. Peaks in the inclination are labelled B-E.

1983) exact detailed correlations will have a limited areal extent. In addition, a possible westward drift of the geomagnetic field (the present day rate is c. $0.2^{\circ} /$ $y$ towards the west) may shift the expected timefit of indvidual peaks.

The general nature of the records is very similar to those obtained from Holocene lake sediments in NW Europe (Turner \& Thompson 1981, Readman \& Abrahamsen 1988, 1990). The time resolution possible with the present sediments may be better on ac- 

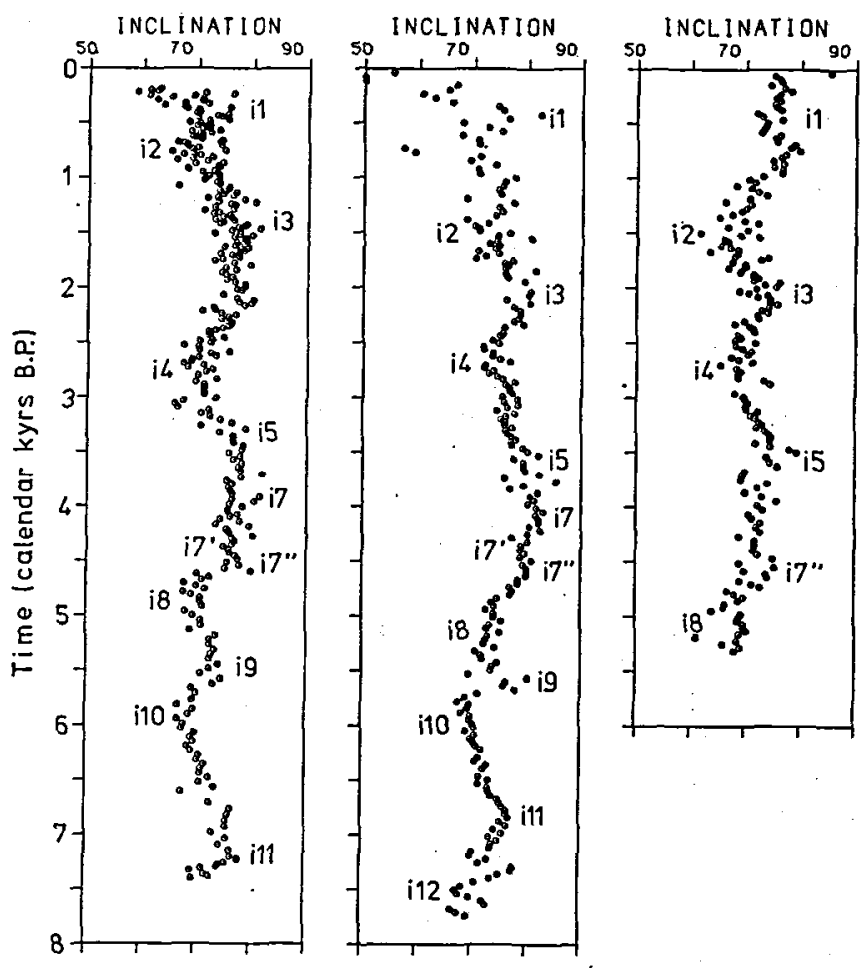

b) Skanderborg
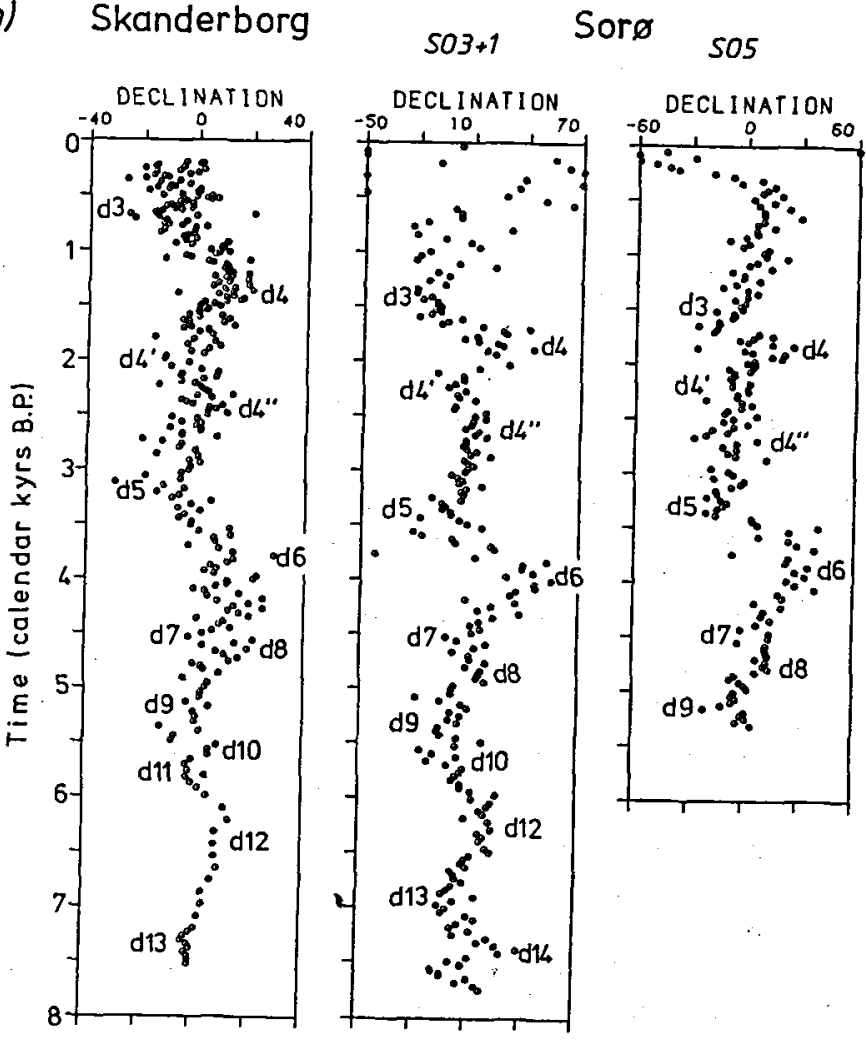

Figure 10. Declination and inclination in Holocene lake sediments from Lake

Skanderborg and Lake Sorø in Denmark.

Reproduced from Readman \& Abrahamsen (1990). 
count of the faster deposition rate, but this is partly negated by the higher experimental scatter, particularly in the case of the inclination because of the grain size dependant inclination error noted above. The timescale of the variations observed in Holocene records is, in general, in the range 300-1000 years, with clearly a considerable variation within the whole period. The type of variations observed at $\mathrm{Nr}$. Lyngby thus fit into the general pattern observed through the Holocene.

The declination at the base of section $\mathrm{A}$ is easterly (average $\sim 60^{\circ} \mathrm{E}$ or more) which is similar to the main trend found in the upper half of the nearby YoungerYoldia sequence (Abrahamsen \& Readman 1980). The top of the younger Yoldia profile has an age of about $13500 \mathrm{BP}$ and the age of the base of the present profile is around $12000 \mathrm{BP}$. Unfortunately there are no data available in Denmark for the intervening $\sim 1500$ years. These two results do suggest, however, that the field may have had a tendency to be easterly during the Late Weichselian. Whether this was a persistent direction can only be tested if more data become available.

For comparison with the Holocene magnetic secular variation pattern as recorded in danish lake sediments (gyttjas), the declination and inclination curves from Lake Skanderborg and Lake Sor $\varnothing$ (Readman \& Abrahamsen 1990) are reproduced in Figure 10. The gyttjas in the lakes are more homogeneous, and probably therefore the directional scatter in these sediments are much less, hence revealing more destinctly defined patterns of magnetic secular variation than those recorded in the Late Weicheselian, typically more sandy sediments.

\section{Conclusions}

The variations in declination and inclination over a time period of about 1300 years in the Late Weichselian between about 12000 and $10700 \mathrm{BP}$ have been determined using sediments from a former lake in North Jutland, Denmark. Although the quality of the magnetic record obtained from the site at Nørre Lyngby is only moderate, we may conclude that the secular variations compare reasonably well with the magnetic record from Torreberga in southern Sweden, some $350 \mathrm{~km}$ away, and also have similarities with the record from Soviet Karelia, some $1400 \mathrm{~km}$ to the ENE.

We find a long term trend in declination over the timescale represented by the section, i.e. $\sim 1300$ years. Shorter time period variations of about $200-300$ years in the declination and some $600-800$ years in the inclination records are also seen. The latter values are comparable to those found during historic and Holocene times, as well as in the slightly older sequence of the Late Weichselian Younger Yoldia Clay (age about c. 14 600-13 $000 \mathrm{BP}$ ) obtained from core and cliff sites c. $150 \mathrm{~m}$ south of the present profiles (Abrahamsen \& Knudsen 1979, Abrahamsen \& Readman 1980).

It thus appears that the behaviour of the geomagnetic field has been of a similar nature for the last $\sim 14000 \mathrm{yr}$, i.e. for a period considerably longer than the timescale of the variations themselves. This suggests that these types of variations are a permanent feature of the geomagnetic field.

Dependant upon the magnetic properties of the sediment sequences, these secular variation patterns may be useful for future stratigraphical correlations of regional extent, as have previously been demonstrated for Holocene sediments.

\section{Acknowledgements}

The investigation is part of the project 'Geomagnetism, environment \& climate'. Financial support provided by the Danish Natural Science Research Council is acknowledged. We also benefitted from discussions with Karen Luise Knudsen about the strati-graphy, and from calculations of the radiocarbon calibrations by Kaare Lund Rasmussen.

\section{Dansk sammendrag}

Med henblik på at bestemme den geomagnetiske sekularvariation i Danmark i Senglacial tid, er ca. 400 orienterede palæomagnetiske sedimentpr $\varnothing \mathrm{ver}$ blevet indsamlet og magnetisk unders $\emptyset$ gt, jfr. Fig. 2 og 3. Prøverne stammer fra det klassiske kystklint-profil i de Senglaciale ferskvandslag ved Nørre Lyngby i Nordjylland (Jessen \& Nordmann 1915, Jessen 1931, Krog 1978, Aaris-Sørensen 1995), hvor data er bearbejdet fra to tætliggende profiler A og B, der dækker Allerød-lagserien (alder ca. 11800 til ca. $11000 \mathrm{BP}$ ) samt de nærmeste omgivende lag, der således dækker et samlet tidsspan mellem ca. 12000 og ca. 10700 BP (Figur 4).

Den magnetiske intensitet er lav i de sandede nedre og øvre dele af lagserien (Fig. 4), hvorfor de magnetiske retningsresultater (deklination og inklination) fra disse sandede sedimenter er ret spredte og formentlig mindre pålidelige i deres registrering af jordmagnetfeltets retningsvariationer. Derimod er de midterste, ca. $2 \frac{1}{2} \mathrm{~m}$ mægtige, gytjerige dele af de limniske sedimenter mere finkornede og har en kraftigere magnetisering (Fig. 4). De giver derfor en mere pålidelig registrering af den naturlige remanente magnetisering (NRM) i sedimentet, og dermed også af det daværende jordmagnetfelts retning. Den magnetiske retning er som vanligt angivet ved de to vinkler deklination (svarende til den magnetiske misvisning) og inklination (vinklen mellem magnetfeltet og det vandrette plan). 
Udsvingene er markeret med bogstaver ( $a-k$ i Fig. $8 a$ og 8b, samt A-F i Fig. 9a og 9b).

Der er fundet fem svingninger i deklinationen (som var domineret af østlige værdier, jfr. Figur 8a) med perioder på omkring $200 \mathrm{ar}$, samt godt to svingninger $\mathrm{i}$ inklinationen (Fig. 9a) med en periode på ca. det dobbelte. Disse perioder er sammenlignelige med tidligere resultater fra den lidt ældre sekvens af Yngre Yoldia Ler ved Nørre Lyngby, der har en alder på omkring $14000 \mathrm{BP} \pm 500$ àr, og som er mảlt sảvel i boringer (Abrahamsen \& Knudsen 1979) som i et kystprofil beliggende ca. $150 \mathrm{~m} \mathrm{~S}$ for profil A og B (Abrahamsen \& Readman 1980). Det ser altså ud til, at disse kort-tids variationer i magnetfeltets retning, som endog kan måles endnu tydeligere i Holocene s $\varnothing-$ gytjer (Fig. 10), har været karakteristiske for den geomagnetiske sekularvariation i det mindste gennem de sidste ca. 14000 år, d.v.s. for et tidsrum der er meget længere end udsvingenes egen varighed på kun nogle få hundrede år.

En sammenligning med tilsvarende palæomagnetiske resultater fra de senglaciale sedimenter i Torreberga Bassinet i Skåne (Sandgren 1986; Ising 1990) ca. $300 \mathrm{~km}$ sydøst for $\mathrm{Nr}$. Lyngby viser, at der på trods af afstanden samt den statistiske spredning i resultaterne er en rimelig overensstemmelse mellem de fundne geomagnetiske svingninger for de to lokaliteter. Også magnetiske resultater fra Russisk Karelen c. $1400 \mathrm{~km} \emptyset \mathrm{N} \emptyset$ for Nr. Lyngby (Bakhmutov \& Zagniy 1990), som dækker hele Senglacial Tid i dette område $(16000-10000 \mathrm{BP})$ viser en vis korrelation med Nr. Lyngby, idet det østlige sving (g) i deklinationen fra Nr. Lyngby (Fig. 8a \& 8b) fortolkes at svare til en østlig cluster af punkter for Karelen omkring 11100 BP. Også et udpræget østligt sving omkring 12000 $\mathrm{BP}$ ses på begge lokaliteter, mens høje værdier $\mathrm{i}$ inklinationen mellem 12000 og 11700 BP i Karelen foreslås at svare til de generelt høje værdier i Nr. Lyngby mellem 11600 og $11300 \mathrm{BP}$.

\section{References}

Aaris-Sørensen, K. 1995: Paleoecology of Late Weichselian vertebrate fauna from N. Lyngby, Denmark. Boreas 24, $355-365$.

Abrahamsen, N. 1982: Pleistocene-Holocene magnetostratigraphy at Solberga, Brastad and Moltemyr, SW Sweden. Sveriges Geologiska Undersökning C 794, 93-119.

Abrahamsen, N. 1995: Paleomagnetic investigations in the Bornholm Basin. In Emelyanov, E., Christiansen, C. \& Michelsen, O. (eds): Geology of the Bornholm Basin; Aarhus Geoscience, 5, 55-63.

Abrahamsen, N. \& Knudsen, K. L. 1979: Indication of a geomagnetic low-inclination excursion in supposed Middle Weichselian Interstadial marine clay at Rubjerg, Denmark. Physics Earth and Planetary Interiors 18, 238246.

Abrahamsen, N., Nybakken, S., Gillebo, T. \& Sørensen,
R. 1995: Palaeomagnetism and stratigraphy of Late Younger Dryas and Holocene sediments in Lake Årungen, southeastern Norway. Norsk Geologisk Tidsskrift $75,37-47$.

Abrahamsen, N. \& Readman, P. W. 1987: Quaternary magnetostratigraphy in Denmark. Boreas 16, 373-380.

Abrahamsen, N. \& Readman, P.W. 1980: Geomagnetic variations recorded in Older (>23000 BP) and Younger Yoldia Clay ( $14000 \mathrm{BP})$ at Nørre Lyngby, Denmark. Geophysical Journal Royal astronomical Society 62, 329-344.

Aitken, M. 1970: Dating by archaeomagnetic and thermoluminescent methods. Philosophical Transactions Royal Society London, A 269, 77-88.

Bakhmutov, V. \& Zagniy, G. F. 1990: Secular variation of the geomagnetic field: data from the varved clays of Soviet Karelia. Physics Earth and Planetary Interiors 63, 121-134.

Bakhmutov, V., Yevzerov, V. \& Kolka, V. 1994: Geomagnetic secular variations of high-latitude glaciomarine sediments: data from the Kola Peninsula, northwestern Russia. Physics Earth and Planetary Interiors 85, 143153.

Björk, S. 1996: Den dynamiske istid. Varv 1996, 77-103.

Björck, S. \& Sandgren, S. 1986: A 2000 year geomagnetic record from two Late Weichselian sequences in southeast Sweden. Geologiska Föreningen i Stockholms Förhandlinger 108, 21-29.

Björck, S. Sandgren, P. \& Holmquist, B. 1987: A magnetostratigraphic comparison between ${ }^{14} \mathrm{C}$ years and varve years during Late Weichselian, indicating significant differences between the timescales. Journal of Quaternary Science 2, 133-140.

Butler, R. F. 1992: Paleomagnetism: Magnetic domains to geologic terraines. Boston: Blackwell Scientific Publications, 319 pp.

Clark, A. J., Tarling, D. H. \& Noël, M. 1988: Developments in Archaeomagnetic dating in Britain. Journal Archaeological Science 15, 645-667.

Creer, K. M., Hogg, T. E., Malkowski, Z., Mojski, J. E., Niedziolka-Krol, E., Readman, P. W. \& Tucholka, P. 1979: Palaeomagnetism of Holocene lake sediments from north Poland. Geophysical Journal Royal astronomical Society 59, 287-313.

Creer, K. M., Hogg, T. E., Readman, P. W. \& Reynaud, C. 1980: Palaeomagnetic secular variation curves extending back to 13,400 years B.P. recorded in sediments deposited in Lac du Joux, Switzerland. Journal of Geophysics 48, 139-147.

Harland, W. B., Cox, A. V., Llewellyn, P. G., Pickton, C. A. G., Smith, A. G. \& Walters, R. 1982: A geological time scale. Cambridge University Press, $131 \mathrm{pp}$.

Huttunen, P. \& Stober, J. 1980: Dating of palaeomagnetic records from Finnish lake sediment cores using pollen analysis. Boreas 9, 192-202.

Iversen, J. 1942: En pollenanalytisk Tidsfæstelse af Ferskvandslagene ved Nørre Lyngby. Meddelelser Dansk Geologisk Forening 10, 130-151.

Ising, J. 1990: Late Weichselian pollen stratigraphy, palaeomagnetic secular variations and radiocarbon chronology at the Torreberga ancient lake, Skåne, Sweden. Geologiska Förening i Stockholms Förhandlinger 112, 281-292.

Jessen, A. 1931: Lønstrup Klint. Danmarks Geologiske Undersøgelse, II Række, 49, 142 pp. 
Jessen, A. 1936: Vendsyssels Geologi. Danmarks Geologiske Undersøgelse, V Række, 2, 195 pp.

Jessen, A. \& Nordmann, V. 1915: Ferskvandslagene ved Nørre Lyngby. Summary: The freshwater deposits at Nørre Lyngby; Danmarks Geologiske Undersøgelse, II række 29, 66 pp.

King, R. F. 1955: Remanent magnetism of artificially deposited sediments. Monthly Notices Royal Astronomical Society, Geophysical Supplement 7, 115-134.

Knudsen, K. L. 1978: Middle and Late Weichselian marine deposits at Nørre Lyngby, northern Jutland, Denmark, and their Foraminiferal faunas. Danmarks Geologiske Undersøgelse II Række, 112, 44 pp.

Knudsen, K. L., Kronborg, C. \& Lykke-Andersen, H. 1986: Guide to Quaternary Field Excursion, 39 pp., Geological Institute, Aarhus University.

Kovacheva, M. 1980: Summarised results of the archaeomagnetic investigations of the geomagnetic field variation for the last $8000 \mathrm{yr}$ in south-eastern Europe. Geophysical Journal Royal astronomical Society 61, 57-64.

Krog, H. 1978: The Late Weichselian freshwater beds at Nørre Lyngby. C-14 dates and pollen diagram; Danmarks Geologiske Unders $\emptyset$ gelse, Årbog 1976, 29-43.

Lagerlund, E. \& Houmark-Nielsen, M. 1993: Timing and pattern of the last deglaciation in the Kattegat region, southwest Scandinavia. Boreas 22, 337-347.

Lykke-Andersen, H. 1992: Massebevagelser i Vendsyssels og Kattegats kvartære aflejringer. Dansk Geologisk Forening, Årsskrift 1990-91, 93-97.

Mackereth, F. J. H. 1971: On the Variation in the Direction of the Horizontal Component of the Magnetization in Lake Sediments. Earth and Planetary Science Letters 12, 332-338.

Mangerud, J., Andersen, S. T., Berglund, B. E. \& Donner, J. J. 1974: Quaternary stratigraphy of Norden, a proposal for terminology and classification. Boreas 3, 109-128.

Merrill, R. T. \& McElhinny, M. W. 1983: The Earth's Magnetic Field. London: Academic Press, 401 pp.

Nowaczyk, N. R., Friedrichs, T. W., Eisenhauer, A. \& Gard, G. 1994: Magnetostratigraphic data from late Quaternary sediments from the Yermak Plateau, Arctic Ocean: evidence for four geomagnetic polarity events within the last $170 \mathrm{Ka}$ of the Brunhes Chron. Geophysical Journal International 117, 453-471.

Rasmussen, K. L. 1994: Kulstof-14 datering. København: Munksgaard, $63 \mathrm{p}$.

Readman, P. W. \& Abrahamsen, N. 1988: Palaeomagnetism of Post Glacial lake sediments from Skanderborg S $\phi$, Jutland, Denmark. Physics Earth and Planetary Interiors 52, 177-192.

Readman, P. W. \& Abrahamsen, N. 1990: Geomagnetic secular variation from Holocene lake sediments of Sor $\varnothing$ Sø, Denmark. Physics Earth and Planetary Interiors 62 , 4-18.

Saarinen, T. J. 1994: Palaeomagnetic study of the Holocene sediments of Lake Päijänne (Central Finland) and Lake Paanajärvi (North-West Russia). Bulletin Geological Survey Finland 376, 87 pp.

Sandgren, P. 1986: Late Weichselian palaeomagnetic secular variation from the Torreberga basin, south Sweden. Physics Earth and Planetary Interiors 43, 160-172.

Schnepp, E. \& Pucher, R. 1997: Preliminary Archaeomagnetic results from a floor sequence of a bread Kiln in Lübeck (Germany). Studia Geophysica \& Geodaetica 41. (In print).
Smith, G. \& Creer, K. M. 1986: Analysis of geomagnetic secular variations 10000 to 30000 years bp, Lac du Bouchet, France. Physics Earth and Planetary Interiors 44, 1-14.

Stuiver, M. \& Reimer, P. J. 1993: Extended ${ }^{14} \mathrm{C}$ data base and revised Calib3.0 ${ }^{14} \mathrm{C}$ calibration program. Radiocarbon 35, 215-230.

Tarling, D. H. 1983: Palaeomagnetism, Principles and Applications in Geology, Geophysics and Archaeology. London: Chapman \& Hall, 379 pp.

Tarling, D. H. 1989: Geomagnetic Secular Variation in Britain during the last 2000 years. In Lowes, Fj., Collinson, D. W., Parry, J. H., Runcorn, S. K., Tozer, D. C. \& Soward, A. (eds): Geomagnetism and Palaeomagnetism, pp.55-62. Dordrecht: Kuwer Academic Publishers.

Thellier, E. 1981: Sur la direction du champ magnetique terrestre, en France, durant les deux derniers millenaires. Physics Earth and Planetary Interiors 24, 89-132.

Thompson, R. \& Turner, G. M. 1978: British master curve 10 000 -0 yr BP for dating European sediments. Geophysical Research Letters 6, 249-252.

Thouveny, N., Creer, K. M. \& Blunk, I. 1990: Extension of the Lac du Bouchet palaeomagnetic record over the last 120,000 years; Earth and Planetary Science Letters 97, 140-161.

Turner, G. M. \& Thompson, R. 1981: Lake sediment record of the geomagnetic secular variation in Britain during Holocene times. Geophysical Journal Royal astronomical Society $65,703-725$. 